\title{
"Generally Regarded with a Lenient Eye"": Amateur Theatre in Dunedin, 1862-1868
}

\section{LISA WARRINGTON}

The phrase "amateur theatre" often carries an implicit derogatory undertone. It may suggest a group of well-meaning, untrained enthusiasts, awkwardly staging third-rate plays for their friends and families, with a company that might contain one or two moderately skilled performers lost in a sea of essentially bad acting. The pleasure for the audience at such a supposed performance might consist chiefly in being able to laugh at or sympathize with the embarrassment of their friends up on stage. This pattern of excruciating acting coupled with actively mocking audience response dates at least as far back as the appearance of Shakespeare's "rude Mechanicals" in A Midsummer Night's Dream. Certainly in colonial New Zealand and Australia, the general assumption might be that that the audience was likely to require considerable forbearance to sit through an amateur performance, and that many allowances would have to be made - or not. Perhaps the nadir of colonial amateur endeavour at this period can be found in the efforts of Melbourne's Lyceum Amateur Dramatic Club, as recorded in the Argus in May 1862, which:

gave an entertainment to an empty house, for the benefit of the Melbourne Hospital, last night, at the Theatre Royal. When we say "an entertainment," we must be understood as using the word in its merely theatrical sense, for entertainment there was none, except to half-a-dozen facetious boys in the gallery, who recommended the amateurs to "hook it," and sent them an occasional testimonial in the shape of fresh vegetables; ... But the attendance was on a par with the performance, which was a dreary exhibition of signal incapacity on the part of nearly all concerned.... Since the days of Bottom, Quince, and Starveling, we doubt if such an amateur performance was ever seen. $^{2}$

This (no doubt deserved) critical excoriation, however, tells only a very small part of the story of amateur endeavour. In this essay, I seek to examine the rather more complex state of affairs that existed in colonial amateur performance in New Zealand, with a focus on its development in Dunedin. First and foremost, I trace the history of the rise of amateur theatre in Dunedin, virtually side by side with - and inspired by - the advent of professional theatre in the city. I explore the often reductive and oversimplified views of the contribution of amateur actors as expressed by contemporary newspaper criticism, noting certain ambiguities as journalists attempted to take a position that they were forced to retreat from by actual practice. While their memories of "home" might suggest what to expect from amateur performance, it was more difficult to categorize what was actually performed, because of a frequent "slippage" between amateur and professional, perhaps inevitable in a relatively small community, as opposed to a metropolis such as London. A customary critical position for New Zealand journalists appears to have been to expect little, to seek out and record anticipated shortcomings, and then to be pleasantly surprised by any evidence of ability that might present itself. Such a view is exemplified here by the Otago Daily Times reviewer in September 1867:

The amateurs were not wholly free from members who could not look otherwise than uncomfortable on the stage; and that terrible puzzle to non-professionals, what to do with the hands, was occasionally not solved with a graceful result. But there was a good deal of what, for amateurs - and especially for men who had never before attempted to act, which was the case with several last evening-must 
be ranked as good acting; and there was scarcely any of the under-toned hurried talk, which is so often all that is achievable. ${ }^{3}$

In this case, the reviewer drew on those common tropes and expectations of amateur theatricals to demonstrate what was evidently surprisingly good (comparatively speaking) about this particular performance.

While the divide between amateur and professional remained essentially clear, boundaries were often crossed. Both groups were driven by financial considerations. For the professionals, it was a business first and foremost. ${ }^{4}$ For the amateurs, the avowed purpose of performing was to raise funds for designated charities, thus ensuring that pleasure in performing was meliorated by a serious intention. Amateur performances frequently took place in the professional theatres, hired or occasionally donated for the occasion. Friendships were forged which further blurred distinctions, and would eventually allow (for example) the amateur actor B.L. Farjeon to write material performed by the professionals. ${ }^{5}$ Perhaps the most significant element was the blurring of lines that occurred when amateur actors such as T.W. Standwell were invited to perform leading roles with the professionals. Noteworthy as such events might prove to be, it appears that gender bias did not regard the opposite "switchover" as exceptional. The women who appeared in amateur productions were almost uniformly professional actresses "lending their services"-in other words, forgoing payment, which their male counterparts perhaps were more reluctant to do.

In a society with relatively few entertainment resources in the early years, a longing for the refinements of "home" clearly made itself felt. In March 1852, recent immigrant to Canterbury Charles J. Rae wrote to the editor of the Lyttelton Times of his "sincere regret [for] the absence of those means for social intercourse which binds man to man, and of those amusements which tend to make the individual cheerful and virtuous, and society happy." $\mathrm{He}$ noted that the settlement was still too young to expect the existence of a theatre, but wondered "are there not a sufficient number of young men who could form an Amateur Dramatic Club?" Evidently, his pleas fell on deaf ears, since it was not until 1857 that Lyttelton had its own amateur dramatic society "to encourage a taste for the higher drama." As the Lyttelton Times approvingly noted in June of that year, "Dramatic entertainments got up in this way are certainly as innocent and as captivating as any amusements that could be provided to relieve our proverbial dullness; and we therefore do not wonder that the undertaking has received promises of patronage and support in all ways from the ladies as well as the sterner sex in Lyttelton." In such comments, the importance of amateur theatre to the young colony as a civilizing influence is clearly laid out.

However, while it might be imagined that presenting the "higher drama" might be the primary business of amateur theatricals, this was certainly not the only function. Simple entertainment was the key, and if professionals were not there to provide it, the amateurs would create it for themselves. One of the earliest recorded amateur performances took place in Auckland in February 1848, when a "few private gentlemen" got together an amateur dramatic society and offered the farce The Mayor of Garrat and the burlesque extravaganza Bombastes Furioso, "to a full house and an admiring audience." The Daily Southern Cross saw this as a welcome attempt to unite the colonists "for the purposes of relaxation and amusement." ${ }^{8}$ There was an amateur dramatic society in New Plymouth by or before 1855 , which evidently fell into hardship, since in October of that year "the whole of the scenery, machinery and properties belonging to that Society" were to be auctioned off. ${ }^{9}$ Nelson had its own amateur dramatic society by April 1856, and prepared four performances for the Odd Fellows' Hall, "which is being fitted up with stage, scenery, decorations, and all the requisite appliances necessary to the proper production of dramatic representations."10 Wellington's amateur dramatic society opened at the Lyceum Theatre with a vaudeville in three acts entitled Playing for the Odd Trick. ${ }^{11}$. 
Dunedin was relatively late in establishing amateur theatre. Founded by Scottish Presbyterians as a European settlement in 1848, Dunedin was still lacking in suitable and sufficient sources of public amusement in 1862, as the Otago Witness noted, expressing sentiments very similar to those of Charles Rae: "The almost absolute lack of places of amusement has ... had a prejudicial effect, causing Dunedin to seem a gloomy place, in which there was no fun to be had-even the public houses being all by law obliged to close at 10 o'clock." 12 Beyond the attractions of the pubs, concerts were the most readily available form of public entertainment and in 1858-1859, these were provided primarily by a Miss Redmayne, evidently a professional singer and pianist. She offered occasional concerts and literary and musical entertainments, held in the Dunedin School-room, in which her own performance was supplemented by a number of amateurs. An element of competition arose in March 1859, when a Mr. Lowe ("son of Mr. Lowe, of Edinburgh, teacher of the Royal Family at Windsor and Balmoral Castles"13), a gentleman who offered classes in dancing, deportment and callisthenic exercises, also held a concert. The Otago Witness reporter who attended clearly had to bite his tongue:

We cannot afford to be critical upon these occasions in Otago, as we are much dependent upon amateur performers, and any criticism would deter others from coming forward. We may however, without much fear of damaging such entertainments, direct the attention of that class of amateurs who, with more enthusiasm than good taste, favour the audience with a hobnail accompaniment to every popular air, to the fact that their artistical efforts might be dispensed with without any loss being sustained. ${ }^{14}$

Following a Queen's Birthday concert held at the Dunedin Council Hall in May 1860, the Otago Witness again showed displeasure, remarking emphatically that it must have been the charitable purpose of the concert which filled the room, since "it could scarcely have been the music!!!" and that the audience needed to exercise great charity just to listen to it. ${ }^{15}$ The paper was obliged to offer a form of apology several days later, as these remarks were "very ill received by the performers on that occasion, who we now learn were amateurs, or gave their services gratis." 16 This is a particularly interesting response, since it marks a clear boundary between what was deemed appropriate to demand of professionals versus the allowances that propriety deemed had to be made for amateur endeavour. Clearly, the assumption was that the latter had neither the time, the training nor the resources for the kind of rigorous practice that was expected to be demonstrated in professional performances.

How to review an amateur performance was a perennial dilemma, as some of the comments quoted above attest. Quite reasonably, it was generally expected that amateurs could not match the level of the professionals, with rare exceptions. One way of dealing with this issue, occasionally applied, was simply not to name the amateur performers. However, in the interests of art, the Lyttelton Times reviewer, in discussing the local Garrick Club's production of The Rent Day in 1862, expressed a contrary opinion:

To be an actor is one thing; to be an amateur is another. He who strives to become the former will not be aided in his task by indiscreet flattery. To say a man made the most of a given part, means either that it was played naturally, or that it was played as well as such an individual could play it. It is easy to guess which signification the party interested would apply to it. Now, suppose that the amateur has exhibited neither grace nor dignity in the performance; neither humor, vitality, nor pathos; but, on the other hand, has been awkward and stiff in gait, monotonous in tone, and false in emphasis; then that criticism does him real injury, for it feeds vanity, and helps to confirm into habit vices which, properly noticed, might be corrected. The injustice of such criticism does not terminate here-it wrongs the careful student and true genius; for, having commended inanity, it 
cannot rightly honor those to whom honor is due. ${ }^{17}$

While amateur musicians and singers could perform in locations such as the Council Hall and the School-room, it was more difficult to find a venue suitable for professional theatrical performance, which, in the nineteenth century at least, was generally linked with a certain amount of paraphernalia in the form of scenery, machinery, properties, a stage curtain; in short - as noted above by the Nelson Examiner - "all the requisite appliances necessary to the proper production of dramatic representations." 18 The lack of a suitable venue had certainly hampered the visits of professional companies to Dunedin. When the indefatigable American actress Mrs. Foley, with a very small entourage, gave the first of several performances in the city on Boxing Night 1861, they were hailed as "a series of dramatic performances, the first that ever took place in Otago."19 Once Mrs. Foley departed, the city relapsed into theatrical lethargy. Clearly, a key point was the lack of a designated venue for performances, as highlighted by the Otago Witness: "Doubtless the want of a theatre will have operated to some extent in deterring theatricals from visiting Dunedin. This want, we presume, will shortly be supplied by the enterprise of some of the spirited Victorian speculators, who have been attracted to these shores." 20 Those "speculators" were the English-born Fawcett brothers, George, Tom and Sandford, (known as Sandy), who had considerable theatre experience in Melbourne, where George had been lessee/manager of the Princess Theatre since 1859. Tom and Sandy formed an agreement in Dunedin with Shadrach Jones to convert Jones's Horse Bazaar in Stafford Street into a theatre. On 5 March 1862, the grand opening of the Royal Princess Theatre (by day still functioning as a horse bazaar) changed the face of Dunedin public entertainment. $^{21}$

An immediate consequence of the establishment of a professional theatre company in Dunedin was the onset of amateur theatre, with a call for "gentlemen desirous of forming a Dramatic Society," published a mere two days after the opening of the Royal Princess, under the heading "Garrick Club, Otago." 22 The Otago Daily Times saw a direct cause and effect: "The opening of the Theatre appears to have awakened a love of the Drama in the minds of some of the young men of this city ... A Club ... might be exceedingly useful, as well as amusing, if its members were willing to give their services in aid of public charities." 23 An inaugural meeting to gauge interest was held on 10 March 1862 at the Provincial Hotel, which backed on to the Princess Theatre. This led to the foundation of the Dunedin Garrick Club at a second meeting on $13^{\text {th }}$ March. ${ }^{24}$

According to a detailed report in the Otago Daily Times, nine gentlemen met to establish the rules of the club, and virtually all of them became office bearers, with Thomas Hope Baird elected as president, B.L. (Ben) Farjeon as treasurer, W.H. (William Henry) Mumford as secretary, and T. W. (Thomas Winders) Standwell as stage manager. Baird was "a little disappointed at the smallness of the meeting, but he trusted that paucity in numbers would not interfere with the object in view." The report of the meeting shows much laughter and good humour on the occasion, with Ben Farjeon, on his nomination as treasurer, remarking that "whatever might be thought of his capabilities in a general sense, he claimed credit to himself for being a good hand at taking money (laughter.)." So verbose were their deliberations that "Mr. Lloyd expressed his private opinion that on the first night of performance, the Garrick Club of Dunedin should play 'Raising the wind' - (laughter)." Each member paid a guinea to provide inaugural funds, and discussion ensued as to an appropriate play for their first performance. It was agreed that Farjeon, as treasurer, "procure books from Melbourne, per return of the steamship 'Aldinga'.,"25

The formation of the Garrick Club was in accordance with common practice for amateur dramatic societies of the time. First and foremost, all of the members were men, educated and of the "professional" working class. For example, Mumford was at that time a shipping agent, Farjeon worked at the Otago Daily Times, ${ }^{26}$ where Standwell was also a 
printer/compositor, and (most likely) Alexander Cumming and Alfred Barnett were both auctioneers. ${ }^{27}$ Most of them were in their mid- to late twenties at that time, and the majority had emigrated from England or Scotland, some of them (including Mumford, Standwell and Farjeon) having arrived via Victoria. ${ }^{28}$ Only one performance of any piece was generally given (which might readily explain some of the common shortcomings) and it was understood that all performances were undertaken with a specific charitable objective, the funds raised at the box office going to nominated good causes. Women did not generally participate in public amateur theatricals in those early years. When it came to performances, it was expected that professional actresses would be gracious enough to "lend their services" to play the female roles. As a rare exception to this rule, an unnamed lady amateur appeared on stage with the Dunstan "Histrionic Club" at the Victoria Hotel on 30 June 1863. In this case, the amateurs appeared alongside professional actors and actresses who had travelled to the Dunstan from Dunedin, and played two pieces, in the second of which, a farce entitled Boots At the Swan, the role of Emily was played "by rather an uncommon personage, a Lady Amateur, who sustained the character very nicely." 29

The general activities of the newly formed Garrick Club were evidently seen as newsworthy, which provides a valuable record of the rehearsal process for an amateur company. For their first performance, the Club had selected Edward Bulwer-Lytton's play Money (1840) at a meeting on Monday 17 March, and two days later, the roles were cast. Presumably, at least one of the gentlemen amateurs already owned a copy of the script of this popular and quite sophisticated comedy. By this date (19 March), membership numbers had risen, enthusiasm was high, and "the Treasurer's report showed an encouraging balance." 30 On the evening of Wednesday 26 March, a rehearsal meeting was called, although frustratingly, the paper records that "the proceedings being purely of a private character, any special report is precluded." ${ }^{\prime 1}$ From first recorded rehearsal to performance on 25 April was a period of four weeks - about the same length of time that a modern professional theatre company might give to full-time rehearsals of a play. In marked contrast, for the first fortnight the amateurs held one rehearsal each Wednesday, at the Provincial Hotel, for the first fortnight, their presence requested "by order" of the secretary, W. H. Mumford. After that, the pace picked up a little, with a second weekly rehearsal on Saturday 12 April, and full stage rehearsals at the Princess Theatre, at 2pm sharp on Wednesday 16 April and on Saturday 19 April, for which "acting members are requested to be present." The final rehearsal appears to have taken place on stage at the Princess Theatre at 2pm sharp on Wednesday 23 April, with a special meeting at the Provincial Hotel on the evening of Monday 21 April, "when all the appointments were successfully completed for the production.",32

The rehearsal times-evenings, generally from $8 \mathrm{pm}$, and some Wednesday and Saturday afternoons, often from $2 \mathrm{pm}$ - were doubtless made possible by the Early Closing movement, which gained ground in Dunedin early that year. For example, a number of wholesale firms advertised their intention to close every Saturday at $2 \mathrm{pm}$, while the Otago Daily Times observed with approbation that "the Early Closing Movement has extended to Dunedin, and ... the agitation for short hours in shops has been successful ... fourteen firms ... agreed to close their shops at 7 o'clock every evening, commencing on Monday next." 33 The Princess Theatre, under the management of Tom and Sandy Fawcett, evidently made some effort to accommodate these afternoon rehearsals on stage by the amateurs, since there was generally a very high turnaround of plays by the professional company, and one would expect the actors to be using the stage themselves during the daytime, in order to prepare for each of the new evening performances. As it happens, on Wednesday 16 April, the professionals were giving the third of three performances of that "new sensation drama" The Gipsy Farmer, which perhaps eased their rehearsal needs-although 17 April saw a "grand change of performance" with the opening of a double bill comprising the drama Don Caesar De Bazan, and the "screaming farce" of The Spectre Bridegroom. 
Money, performed at the Princess Theatre on Friday 25 April 1862, was regarded as a brilliant début, with a crowded house in which "every seat was occupied and standing room was at a premium." ${ }^{34}$ It seems very likely to have been the first performance of the play not only in Otago but also in New Zealand. As a reminder of the customary expectations of amateur performance, the review drew particular attention to the fears that the actors might "break down": "fears, perhaps, in some instances, not altogether unmixed with hopes, for so perverse is human nature that the friends and acquaintances of amateur performers usually, we fear, look upon it as very good fun for them to be stuck or to make a regular muddle of their parts."

In the event, the performance passed off very well, with only a couple of slight "hitches," received in good humour by the audience. The single biggest fault found by the reviewer was that the opening scene was almost inaudible, since there was too much movement and "buzz" from the audience, and the actors had not correctly judged the volume required to fill the theatre, especially given that the building was "so badly adapted for the conveyance of sound." They quickly adjusted, however, with the exception of Mr. Fuller, as Captain Dudley Smooth, "who throughout was frequently inaudible." Cast members-13 in total—included A. A. Barnett as Lord Glossmore, W.H. Mumford as Sir Frederick Blount (a character who, according to Lytton's script, "objects to the letter R as being too wough, and therefore dwops its acquaintance" [(Money act one, scene one]), Thomas Baird as Sir John Vesey, and T.W. Standwell as the hero, Alfred Evelyn. B.L. Farjeon played Mr. Graves, a legal executor, "who is always in black-always lamenting his ill fortune and his sainted [dead wife] Maria, who led him the life of a dog" (Money, act one, scene one). The reviewer felt that Graves was "capitally played" by Farjeon, "who provoked roars of laughter by his humorous portrayal of the melancholy but kindly widower, whose grief for his 'Sainted Maria' cannot blind him to the fact that Lady Franklin is a remarkably fine woman." The review singled out for especial praise Mr. T.W. Standwell, who "exhibited histrionic ability of a class rarely found among amateurs. With a fine rich voice, a good stage manner, and a degree of aplomb, such as would have done credit to a practised actor, Mr Standwell showed also that he had that appreciation of the niceties of the author's meaning." The performance received very hearty applause, as did the Scottish dance that followed, which evoked a "rapturous encore."

Professional actresses graciously played the three roles for women: Miss Ada Hart (as Clara, the romantic heroine), Miss Kate Corcoran (as her love rival, Georgina Vesey), and Miss Emma St Clair as Lady Franklin, who takes a strong interest in widower Mr. Graves. By definition, then, this was not entirely an amateur performance, though here, as in reviews of sundry other productions, the reviewer scarcely, if at all, reflects on this fact. While polite comments were made on their performances, no clear distinction was made between the professional women and the amateur gentlemen of the company. Indeed, Ada Hart was damned with faint praise, her performance deemed to have demonstrated "a degree of pathetic force for which we have hardly given her credit before." The women's greatest noted contribution was that, "by dressing appropriately for each act, [they] added greatly to the picturesque effect." Condescension of this type was of course not uncommon at the time. ${ }^{35}$ Money was preceded by a prologue, especially written for the occasion by Ben Farjeon, who also spoke it. Farjeon's 71-line prologue, in rhyming couplets, patriotic and comical by turns, drew conventional comparisons between the memory of a peaceful, rural, contented England and a new land categorized as harsh, wild, savage, uncultured and ignorant, but redeemed by the smiling faces present in the theatre:

Instead of savage forms and rugged scenes,

I see but pegtops and huge crinolines. 
Farjeon also managed a little jest about the double-function of the building, referring to the audience "in box-in pit - and - (not in horse's) stall." He ended the prologue with a further jest, in which the prompter supposedly interrupts his mock-learned discourse on the subject matter of the play, ringing the bell to get him off the stage. ${ }^{36}$ This was Farjeon's first minor contribution as a writer for the stage, but it would signal the start of a fruitful relationship with the professional theatre in the near future.

The gross receipts for the performance totalled $£ 153.16$ s.6d, with $£ 89.9$ s incurred in expenses, made up of: "Hire of theatre, $£ 60$; printing, advertising, and posting, $£ 19$ 7s; cheque takers $£ 4$; and incidental expenses attending rehearsal and performance, $£ 6 ~ 2 s . " 37$ It is particularly interesting to note here that the theatre had no intention of making its own charitable donation, other than that contributed by the three actresses who gave up their salary for the evening. This left a balance of $664.7 \mathrm{~s} .6 \mathrm{~d}$, which Farjeon, as treasurer, was instructed to forward to the nominated charity, the Dunedin Benevolent Asylum. In fact, the Garrick Club had originally planned to give the proceeds to the Dunedin hospital, but an editorial in the Otago Daily Times had strongly suggested that they reconsider, since perhaps they were "not aware that the Hospital is a Government Institution, not in any way dependent upon voluntary contributions [with no] officer authorized to received donations on its behalf." Instead, the writer firmly advised, they might wish to give the money to the Benevolent Asylum, "an institution which is intended to be entirely dependent upon public charity." 38 The charitable purpose of the performance even inspired a riddle, submitted to the Otago Daily Times:

"Why are the members of the Dunedin Garrick Club like the banker who sent off $£ 1000$ in gold from London by coach, to enable a friend in the country to meet his liabilities?" Answer- "Because they are putting money on the stage for charitable purposes!"39

T.W. Standwell, the most experienced performer, was chosen by the members to be their "stage manager," which in nineteenth-century theatre roughly equated to the position of a modern director. The stage manager was responsible for calling rehearsals, arranging any stage pictures required by the positioning of the actors, and generally overseeing the performance - though the notions of "a concept," of character motivation or of ensemble work, or indeed many of the functions of a modern director, were not part of his brief. A "good" actor should know their lines, have a powerful and compelling voice and stage presence, and have an idea of the history and traditions of the role formed by those who had preceded him. A "great" actor would make the role their own, and perhaps introduce new stage business or readings of the lines that would thrill and astonish the audience. Such matters were clearly believed to be beyond the brief and the general skills of the amateurs.

Standwell himself was an exception to this. Born in Lincolnshire, he had emigrated to Victoria, where he evidently participated in amateur theatricals, and from there had recently come to Dunedin, taking up his job as compositor at the newly established Otago Daily Times. He was unquestionably gifted as an actor, but for whatever reason, showed no inclination to enter the profession. On 6 February 1862, he was one of several amateurs who had "kindly volunteered their services for that night only" to appear opposite Mrs. Foley in the comedy Time Tries All. He took on the male lead, Matthew Bates, while Mrs. Foley played his cousin Laura, with whom he is in love, but for whom he must wait three years to test her love for him. ${ }^{40}$ So well did he carry off this part that "on the fall of the curtain [Mrs Foley] and $\mathrm{Mr}$ Standwell were loudly called for, and were greeted with immense applause when they appeared. ${ }^{, 41}$ In addition to stage managing the inaugural Garrick Club production of Money, Standwell again took one of the leading roles, playing the hero, an impoverished student named Alfred Evelyn, whose unexpected inheritance sets much of the plot (and the play's social commentary) in motion. 
Having played the role of Evelyn in Money with great credit, Standwell must have sufficiently impressed the Fawcetts for them to invite him to appear as Othello in a benefit performance for Sandy Fawcett, given at the Princess Theatre on 28 May 1862. This was claimed - inaccurately - to be the first time Shakespeare's tragedy of Othello had been played in New Zealand. The Otago Daily Times awaited the event with pleasurable anticipation, "especially as the chief character is to be sustained by an amateur, who has already shown histrionic ability of no ordinary stamp." 42 As was the custom, the actor playing the leading role received the lion's share of the review - in this case, the amateur, even though he played opposite professionals, who included Mr. Wolfe as Iago, Tom Fawcett as Cassio, and Miss Ada Hart as Desdemona. It is worth noting that this was not always the case-for example, when an amateur actor had played Iago opposite the professional Mr. Kemble Mason as Othello at Hobart's Royal Victoria Theatre in May 1854, the review merely noted: "Of the performance of Iago it would be unfair to speak critically; it was a very fair piece of acting, and gave much satisfaction." 43 But in Standwell's case, the performance was seen as something of a triumph:

Seldom ... has it been our fortune to see an amateur succeed so completely in the impersonation of a great tragic character. As a rule, amateurs, in attempting tragedy, are either weak, or else rush into the opposite extreme of ranting. ... Mr. Standwell ... entered into the part with real ardor, and pourtrayed [sic] with nice appreciation the mingled passions of the fierce and untamed, but noble hearted Moor. His fine rich voice and manly bearing told well, and bore him through where a man of less physique must have broken down. His conception of the character was good, and as is usually the case with enthusiastic amateurs, sufficiently idealized to lift it out of the ordinary groove of conventional acting; and taken as a whole the impersonation was a really surprising effort. It must not be supposed that it was without fault; but the faults were exactly those which greater practice, and a more accurate knowledge of stage effect would surely correct. The worst fault and the most difficult to get over, was in the pronunciation of certain words, in which a provincial accent could be detected. ${ }^{44}$

Standwell also took a leading role in the second Dunedin Garrick Club offering, Douglas Jerrold's "beautiful drama" The Rent Day (1832), in which, as Farmer Martin Heywood, his "natural, manly style of acting and excellent declamation told exceedingly well." The Witness reviewer took exception to the costume Standwell chose for this character, believing that "something of the more conventional rustic style" would have been more suitable than the "somber black" he actually wore. In a note which perhaps tells us something about the manner of selecting stage costumes at that time, the reviewer refers to a painting also named "The Rent Day" (1807) by the Scottish artist David Wilkie (1785-1841): "It is, we are aware, by no means looked upon as de rigeur in playing The Rent Day to adhere to the costumes represented in Wilkie's pictures, but at the same time the actor may learn much in the way of effect from the painter." 45

Shortly after this, in September 1862, Standwell left Dunedin and moved to Wellington, where he was later instrumental in founding the Wellington Garrick Club. He was given a "flattering" farewell testimonial by the Dunedin Garrick Club, and was elected an honorary member. ${ }^{46} \mathrm{He}$ continued to make his mark as a performer, playing in Nelson and Auckland as well as in Wellington, and maintaining his connections with the professional theatre. One thing he may well have learned about stage managing in Dunedin was that not all amateur actors could be trusted to attend the precious few rehearsals. This is strongly suggested by the fact that, in 1866, by which time he was stage manager of the Garrick Club in Wellington, Standwell inserted an advert calling for a full dress rehearsal of Damon and Pythias which ended with the stern warning that "fines on acting members will be 
enforced. ${ }^{, 47}$ He worked as a compositor for the Wellington Independent, and also-in 1864 set up (with Mr. Downs) a public swimming baths near Oriental Bay, ${ }^{48}$ a business which later failed, and which may have led to his decision to emigrate to San Francisco, possibly with a wife and two children, where he died unexpectedly of heart disease in June $1870 .{ }^{49}$

Perhaps feeling the loss of Standwell as a driving force, the Dunedin Garrick Club was largely inactive following The Rent Day in August 1862, until February the following year, when they met to decide on a plan of action. They immediately encountered a financial barrier in terms of a one-night lease of the Princess Theatre, now managed by Mr. Clarance Holt and Mr. J. Wolfe. The managers refused an offer of three-fifths of the proceeds (after rent due to the building's owner, Shadrach Jones, had been deducted), and since the Club members considered it "injudicious to give higher terms," they elected to "ascertain if any arrangement could be made with the proprietors of Shamrock Assembly Rooms for a performance on an early date. ${ }^{, 50}$ Perhaps this published report gave them sufficient leverage with the theatre, since four days later, it was announced that the amateurs would give a repeat performance of Money at the Princess Theatre on 27 February 1863, proceeds from which were to be contributed to the Lancashire Relief Fund. ${ }^{51}$

In the event, the performance passed off well, with $£ 113$ taken at the door, from a crowded dress circle, stalls and private boxes, despite the fact that "the pit was somewhat thinly attended." This may have been due to raised ticket prices for the event $-7 \mathrm{~s} .6 \mathrm{~d}$ for the dress circle, $3 \mathrm{~s}$ for stalls, $2 \mathrm{~s}$ for the pit; children in arms $£ 1$; $1 \mathrm{~s}$ to all parts of the theatre. Many club members revived their roles, including Ben Farjeon, and William Mumford as Sir Frederick Blount, "upon whom the effeminate lounginess and affected drawl of the welldeveloped fop seemed to sit lightly." "52 Standwell was replaced as Evelyn by Mr W.W. Wilson, who evidently did a sterling job in a very difficult role. Comments on Farjeon show something of the lighter humour of the comedy:

Mr Farjeon cleverly marked the gradual thaw of Graves's sorrow, under the influence of the merry and bouncing widow, Lady Franklin [on this occasion played by Miss Cassy Matthews]; and the scene between them, where she is determined to make him laugh and dance too, and succeeds in both-making his bane the very antidote of his false maundering, and causing him to skip to the tune of "sainted Maria"-was very cleverly acted by both, and provoked hearty laughter. ${ }^{53}$

Unfortunately for the Dunedin Garrick Club, there appear to have been some anomalies regarding the funds that were collected from this performance. Three months later, "Inquirer" wrote to the Otago Daily Times, asking why there was yet no sign of money contributed by the Garrick Club in the lists of subscriptions to the Lancashire Relief Fund published in the daily newspapers. ${ }^{54}$ Several days after that, the club members were summoned to a meeting at the Provincial Hotel, where the Treasurer (Farjeon) stated that "the person he employed to collect the ticket money for the late performance was evading a settlement, and that he found it impossible to obtain from him the money he had collected."55 There is no clear record of what exactly happened after that, but on 21 November 1863, Mumford as Secretary summoned the Club members to another meeting, "the business being of great importance." 56 This meeting may have signalled the dissolution of the original Dunedin Garrick Club, as nothing more is heard of them.

For the next few years, amateur performance was sporadic in Dunedin. Perhaps some of the Garrick Club members joined the Brook Dramatic Club, which gave a performance in aid of the Job Johnston Defence Fund ${ }^{57}$ at the Theatre Royal on 17 July 1863, where the "gentlemen amateurs" presented The Rent Day and The Honeymoon. (One may perhaps wonder if the repetitions of plays by the amateurs has any connection with available script copies.) They were assisted by Mrs Clarance Holt "and other ladies of the corps, and also by 
Miss Louise Arnot." ${ }^{, 58}$ The Brook Club was no doubt named after the Irish tragedian G.V. [Gustavus Vaughan] Brook, one of the first "stars" to tour widely in Australia, as he did between 1855 and 1861, and who, in July 1863, was rumoured to be coming to Dunedin, under the auspices of George Coppin, who had originally brought Brook to Australia. At that time, Coppin - a great Australian showman, and a comic actor in his own right - had taken a five-week lease at the Theatre Royal, Dunedin, where he initially showcased the Lancashire Bell Ringers, and promised Brook "in a round of Shakespeare and other characters." ${ }^{59}$ As it transpired, Brook never came to New Zealand, and when he was due to return to Australia, in January 1866, he died in a shipwreck en route. The Dunedin Volunteers Amateur Dramatic Club gave a performance on 5 October 1864, presenting the comedy Times Tries All and the farce The Turned Head, but does not appear to have been otherwise very active.

Perhaps in emulation of Tom Fawcett's invitation to T.W. Standwell to play Othello with the professionals, Holt and Wolfe announced, in October 1863, that for Mr Wolfe's benefit night at the Princess Theatre, Macbeth would be presented, and that "two gentlemen amateurs of dramatic celebrity will have the honour of appearing in conjunction with the full strength of the company." 60 They were named as Mr Thomas Little, playing Macbeth, and Mr J. Denny as Macduff, with Mrs Clarance Holt playing Lady Macbeth. ${ }^{61}$ But unlike Standwell, they did not possess the acting chops needed to sustain them:

Perhaps two more difficult characters could scarcely have been selected by the bold histrionics who attempted them. ... An amateur performance is generally regarded with a lenient eye, and the amateurs are almost always favourably received in consequence of some good result being obtainable by their exertions. ... To say that the performers had not studied the words of their parts would be an injustice. Mr. Little and Mr Denny were perfect - there was scarcely a hitch in their mechanical delivery. Word for word was given as Shakspere [sic] wrote, and Macbeth was played to the letter; but the beauties of the poet's creation were entirely lost.

"Gentlemen amateurs" could be found appearing with the professionals - perhaps as a novelty or as a cost-cutting measure-in several further productions in 1864-1865, though none were entrusted with roles as significant as Macbeth or Othello. For example, three of them appeared in unnamed parts in As You Like It, when the most that could be said about them was "that amateurs are entirely out of place when they play with professional actors."

In May 1868, a meeting was held at Wilmot's Hotel, Dunedin, to initiate a new group calling itself the Dunedin Garrick Club, with J.F. Tully appointed as Hon Secretary. No overt reference was ever made to the pre-existence of a Dunedin Garrick Club, but perhaps tellingly, one of its rules reflects knowledge of a possible problem from the earlier group: "The Club, by one of its rules, will make donations of the funds it realises to charitable institutions within the City, as may from time to time be resolved, and will not give special performances for specified charities." 63

The much-heralded inaugural performance, under the highly respectable patronage of the Mayor and city councillors, took place at the Princess Theatre on Monday 10 August. Clearly, there was an expected rubric in writing of amateur performance-or at least, stereotyped phrases which enabled a reviewer to fill his column-since once again, the reviewer seemed surprised to discover that "there was an absence of the ordinary amateur stiffness of bearing and uncomfortableness of movement." ${ }^{, 64}$ The performance was preceded by a "Prize Prologue" for which the Garrick Club had invited entries, won by Mr. V. Pyke, who was presented with "a handsome pencil and pen case, of gold." Pyke's efforts drew particular attention to David Garrick himself, and to the aspirations of the club:

No fitter name for amateurs to take,

Than his, who seem'd to live for Shakepere's sake; ... 
Our aim is pleasure; be that pleasure yours!

Not pleasure only, for our surplus gold

Shall aid the poor, the sick, the feeble, old; ...

In these lines lie the heart of nineteenth-century amateur theatre, represented as clearly in colonial Dunedin as "at home" in London. The key notes are pleasure, a delight in the words of Shakespeare and other great (and lesser) playwrights, and a thoroughly respectable opportunity for young men to get up in a public forum before their peers, and to test their skills against the professionals, while surrounded by goodwill through the charitable object of their endeavours.

Amateur colonial theatre clearly served a variety of purposes, from raising money for charity to providing an outlet for creative expression where none may have previously existed. While some amateur societies rose to fill the void not yet supplied by a professional company, in Dunedin, the two grew virtually hand in glove. As I have shown, there was in fact significant "slippage" between the worlds of the amateur and the professional, which makes that distinction more complex to unravel. The early history of the Dunedin amateur movement, as here outlined, was patchy and lacked a clear drive and perhaps leadership-especially once Standwell left Otago for Wellington and later the United States. In later years, the movement would take much stronger hold, and would see the rise of groups such as the Shakespeare Club, and competing amateur societies. Most significantly in New Zealand, in the early part of the twentieth century, through to about the 1950s, professional theatre virtually disappeared as it was eclipsed by the moving pictures, leaving the amateurs to carry the flag, both as performers and as playwrights. The seeds of that strong desire to sustain the performing arts were laid in the early years when, as Charles Rae noted in 1852, there was a longing for "those means for social intercourse which binds man to man, and of those amusements which tend to make the individual cheerful and virtuous, and society happy."

\footnotetext{
${ }^{1}$ Otago Daily Times, October 24, 1863, 4, from a review of two amateurs appearing with professionals in Macbeth at the Princess Theatre, Dunedin. See later in this article. Note: all newspaper quotations used in this article are sourced from http://paperspast.natlib.govt.nz (NZ) or http://trove.nla.gov.au (Australia).

${ }^{2}$ Argus, May 20, 1862, 5. This review was copied and quoted in full by the Otago Daily Times, May 30, 1862, 4 , and used to draw comparison to the considerably stronger efforts by the amateur Dunedin Garrick Club. The Melbourne Club had performed Tyrone Power's "Grand Military Drama, in three acts, entitled St Patrick's Eve," followed by The Irish Attorney, under the patronage of officers of the Volunteer Corps: "Amusements," Argus, May 19, 1862, 8. The relish of this description puts one in mind of Charles Dickens's account of the unfortunate Mr. Wopsle playing Hamlet in Great Expectations (1861).

${ }^{3}$ Otago Daily Times, September 21, 1867, 4. Note also "It is customary in noticing an Amateur performance, to make liberal allowance for deficiency of professional tact and stage experience ...": Daily Southern Cross, August 12, 1851, 3.

${ }^{4}$ Indeed, an examination of daily performance business records such as those of the professional actor G. V. Brooke show a detailed listing of daily box office takings as the main priority, with only the briefest of occasional comments on the conditions of specific performances.

${ }^{5}$ This falls slightly outside my designated brief for this particular article, but (for example) Farjeon wrote a burlesque of Faust which was first performed by the professional company at the Princess Theatre on August $28,1865$.

${ }^{6}$ Lyttelton Times, March 20, 1852, 2.

${ }^{7}$ Lyttelton Times, June 17, 1857, 6.

${ }^{8}$ Daily Southern Cross, February 12, 1848, 3. According to Peter Downes in Shadows on the Stage (Dunedin: John McIndoe, 1975), 11, the first Auckland dramatic performance-The Lawyer Outwitted - took place in late 1841 in the Albert Theatre (a room at the back of Watson's Hotel), but although this performance may well have been somewhat rough and ready, it was not labelled "amateur," as is further signalled by the presence of a woman-a Miss Wilson-in the cast.

${ }^{9}$ Taranaki Herald, October 3, 1855, 1.

${ }^{10}$ Nelson Examiner and New Zealand Chronicle, April 16, 1856, 2.

${ }^{11}$ Wellington Independent, May 20, 1857, 3, advertisement.
} 
12 Otago Witness, February 15, 1862, 5.

${ }^{13}$ Otago Witness, January 22, 1859, 3.

${ }^{14}$ Otago Witness, March 26, 1859, 5.

${ }^{15}$ Otago Witness, May 26, 1860, 5.

${ }^{16}$ Otago Witness, June 2, 1860, 5.

${ }^{17}$ Lyttelton Times, October 22, 1862, 5.

${ }^{18}$ Nelson Examiner and New Zealand Chronicle, April 16, 1856, 2.

${ }^{19}$ Otago Daily Times, December 24, 1861, 7.

${ }^{20}$ Otago Witness, January 11, 1862, 5.

${ }^{21}$ For detailed information on the establishment of professional theatre in Dunedin, see Lisa Warrington, "We are amused: Theatre comes to Dunedin, December 1861-April 1862," Australasian Drama Studies 62 (2013), 41-54.

${ }^{22}$ Otago Daily Times, March 7, 1862, 5.

${ }^{23}$ Otago Daily Times, March 8, 1862, 4.

${ }^{24}$ The original Garrick Club, named after the famous actor David Garrick (1717-1779), was founded in London in 1831, as a place where "actors and men of refinement and education might meet on equal terms" (see http://www.garrickclub.co.uk). Many amateur dramatic groups subsequently formed as Garrick Clubs in New Zealand and Australia, amongst other countries. Canterbury established a Garrick Club in April 1862, while Oamaru's Garrick Club gave its first performance in September 1867-with a special prologue for the occasion written for them by B. L. Farjeon.

${ }^{25}$ Otago Daily Times, March 14, 1862, 4.

${ }^{26}$ Different sources suggest different jobs held by Farjeon-perhaps he held all of them. Raewyn Dalziel names him as the Otago Daily Times's business manager in Julius Vogel: Business Politician (Auckland: Auckland University Press, 1986), 36, and he certainly arrived in Dunedin with Julius Vogel, the inaugural editor. A Press Association obituary states that he "assisted [Vogel] in founding [the paper and] was a compositor on the paper and later he became its sub editor." Reprinted in Marlborough Express, July 27, 1903, 2.

${ }^{27}$ Certainly, men with these names were Dunedin auctioneers.

${ }^{28}$ The Oases database at Toitū, the Otago Settlers Museum, lists men of these names (excluding Standwell), many born around 1835. Farjeon was born in London in 1838, and he and Vogel (who were related) had gone to Victoria to try their luck on the goldfields, quickly moving on to other occupations.

${ }^{29}$ Otago Daily Times, July 4, 1863, 6.

${ }^{30}$ Otago Daily Times, March 20, 1862, 4.

${ }^{31}$ Otago Daily Times, March 27, 1862, 4.

32 Otago Daily Times, April 22, 1862, 4.

33 Otago Daily Times, February 10, 1862, 3; Otago Daily Times, March 5, 1862, 4. On that same date, a Letter to the Editor, signed by "An Assistant," made its own impassioned pleas for early closing: "From the long and protracted hours of business we have been sujected to as a class, we are denied in great measure the pleasure of either mental or bodily recreation, and it could be easily shown that the advantages arising from early closing would be mutual, as purchasers are generally better pleased with what they buy by the light of day." Otago Daily Times, March 5, 1862, 4.

${ }^{34}$ Otago Daily Times, April 26, 1862, 5. So crowded was it that it became "anything but comfortable to the audience, for as a few of the latest comers persisted in standing up in front, the great body of the audience caught only occasional glimpses of the stage. It would be well on any future occasion to make some arrangement to prevent the admission of more people than the seats will accommodate."

${ }^{35}$ Otago Daily Times, April 26, 1862, 5.

${ }^{36}$ The Otago Daily Times published Farjeon's Prologue in full, as part of their review of the event, April 26,

1862 , 5. Given that Farjeon worked at the paper, no doubt he supplied them with a copy.

${ }^{37}$ From a report of a general meeting of Club members, Otago Daily Times, May 8, 1862, 4.

${ }^{38}$ Otago Daily Times, March 21, 1862, 4.

${ }^{39}$ Otago Daily Times, April 25, 1862, 4.

${ }^{40}$ For further plot details see, for example, a review of the Casterton Dramatic Club's performance of the play in Border Watch (Mount Gambier, South Australia), May 27, 1885, 2. Many reviewers commonly filled up their column with a detailed plot summary, as given here.

${ }^{41}$ Otago Daily Times, February 7, 1862, 2.

42 Otago Daily Times, May 28, 1862, 4.

${ }^{43}$ Courier [Hobart], May 27, 1854, 2.

${ }^{44}$ Otago Daily Times, May 29, 1862, 4. It is certainly possible that Farjeon or even Vogel himself was the author of this review.

${ }^{45}$ Otago Witness, August 30, 1862, 2. 
${ }^{46}$ Otago Daily Times, September 23, 1862, 4.

${ }^{47}$ Wellington Independent, April 19, 1866, 4.

${ }^{48}$ There are sundry articles about the establishment and later failure of the swimming baths. See, for example, Wellington Independent, December 1, 1864, 2.

${ }^{49}$ Perhaps ironically, two of the less gifted amateurs went on to engage with professional theatre. William Mumford, after falling in love and making a runaway marriage with Miss Julia Matthews, one of the shining lights of the professional stage, took the risk of giving up his job and taking a lease as manager of the Princess Theatre. Unfortunately, it was a gamble that did not pay off, and he was declared insolvent in March 1866: Otago Daily Times, March 7, 1866, 6. B.L. Farjeon would go on to a very successful career as a novelist based in London, having first toyed with a number of theatrical writing ventures in Dunedin's professional theatre. His theatre work - and that of Julius Vogel — will be the subject of a forthcoming article I am currently working on.

${ }^{50}$ Otago Daily Times, February 12, 1863, 4.

${ }^{51}$ The Lancashire Relief Fund was high on the charitable conscience of New Zealand and Australia at that time, and was intended to support "those operatives in the Lancashire manufacturing districts, who, through the disruption of trade consequent on the American war, have been thrown out of employment." Letter to the Argus in Melbourne, Otago Daily Times, August 4, 1862, 5. In Christchurch, for example, the newly formed Canterbury Musical Society was planning to give a concert in aid of the fund: Otago Daily Times, October 21, $1862,5$.

${ }^{52}$ Otago Daily Times, February 28, 1863, 4.

53 "Amateur performance by the Garrick Club," Otago Daily Times, February 28, 1863, 4.

${ }^{54}$ Otago Daily Times, May 5, 1863, 5.

${ }_{56}^{55}$ Otago Daily Times, May 11, 1863, 4.

${ }^{56}$ Otago Daily Times, November 21, 1963, 3.

${ }^{57}$ The story of Job Johnston, a gold miner wrongly accused of murder, forced to use all his money to clear his name in court and obtain his freedom, was extensively reported in the press in 1863. The public was deeply sympathetic with his plight, and the fund was commenced to help reimburse him for his very heavy court costs.

${ }^{58}$ Otago Daily Times, July 18, 1863, 4.

${ }^{59}$ Otago Daily Times, July 13, 1863, 4.

${ }^{60}$ Otago Daily Times, October 23, 1863, 6.

${ }^{61}$ The critic's note on her performance - "an earnest and praiseworthy piece of acting"-is a polite "filler," which on the one hand tells us very little about the nuts and bolts of the way she approached the role, and on the other hand, may have been just, if she in fact was treating it primarily as an exercise in elocution.

${ }^{62}$ Otago Daily Times, May 14, 1864, 4.

${ }^{63}$ Otago Daily Times, August 11, 1868, 2.

${ }^{64}$ Otago Daily Times, August 11, 1868, 2.

${ }^{65}$ Lyttelton Times, March 20, 1852, 2. 